\title{
バイオテクノロジーと乳酸菌研究
}

\author{
佐々木 隆*
}

\section{Biotechnology and Current Research on Lactic Acid Bacteria}

\author{
SASAKI Takashi* \\ * Central Research Institute, Meiji Milk Products Co., Ltd., \\ 540, Naruda, Odawara Kanagawa 250-0862
}

近年，バイオテクノロジーの進展によって生命現象が 深く解明され，次々に膨大な情報が得られた結果，旧来 の生命観の変更が迫られるなどその影響は広く各分野に 及んでいる。言うまでもなく, バイオテクノロジーはす でにわれわれの生活に樑く根をおろしており，人類が受 けている恩恵はきわめて大きい。たとえば，各種医薬品 の製造をはじめ食品の加工や製造にもバイオテクノロジ 一が大いに役立っており，その利用は今後いっそう盛ん になるであろう。食品製造と密接に関係する乳酸菌でも 近年バイオテクノロジーが進展し, 食品はもちろん健康 関連分野でも乳酸菌の応用を目指寸研究が活発に行われ ている。

食品の製造，研究などにたずさわる人間にとってバイ オテクノロジーを正確に理解することはますます重要に なると思われるが, この技術についてあまり詳しくない 読者もおられると思い，本文ではまず微生物について簡
単な紹介をしたのち，バイオテクノロジー，特に細菌の バイオテクノロジーの理解に役立ついくつかのポイント について私なりの解説を試みる。そして最後に, 乳酸菌 のバイオテクノロジーに関する動向を紹介したい。

本文は，本年 2 月 4 日に東京農業大学で開催された IFT Japan講演会で行った話をもとにして気軽に読ん でいただける読み物となることを目指して書いた。

\section{1 細菌のバイオテクノロジー}

\section{(1) 微生物とは?}

現在の地球上の生物を大別すると, 動物・植物・微生 物などに分類される。これらは同一の祖先から長時間に わたる進化の結果生まれたものである。すなわち, 今か ら 46 億年前に地球が誕生したが, その後約十億年にわ たる化学進化を経て最初の生命体 (単細胞生物と考えら れる原初生物）が生まれた（Fig. 1参照)。

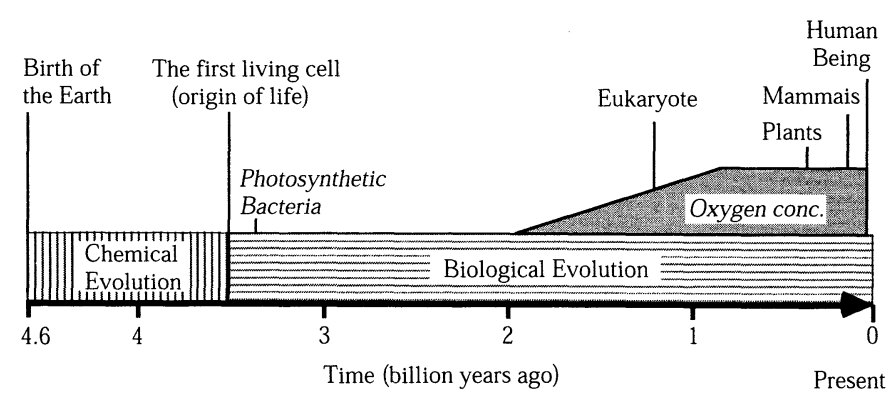

Fig. 1 Historical view of living things on the earth 
その最初の生命体から派生し約35億年もの長時間の 末に，想像を超える多様で複雑な生物進化を経て子孫を 残したのが現存する生物である。動物や植物は目に見え るのでその形も作用も理解しやすいが，微生物は人間の 目には見えない小さな存在であるため日常生活で意識さ れることはほとんどない。

微生物の存在が認識されたのは，17世紀にオランダ のレーウェン・フックが自作の顕微鏡で各種細胞や微小 生物の形態を観察したのが最初だとされている。そして, 微生物が自然発生するのではなく各々の親から生まれて 増殖することや，微生物の中にはブドウ酒の発酵などを 行う酵母のように人類に役立つものもあるが，コレラや ペストなど伝染病の原因になるものもある，ということ が理解されたのは19世紀後半になってからである1)。

微生物は多様であり様々な作用を及ぼしているが，人 間は自分の都合によって微生物を区別する。発酵食品や 抗生物質など有用な物質を作ったり, 環境浄化に役立つ ものなどを有用微生物（有用菌）と呼び，病気の原因と なったり，毒素を生産し，または食品を腐らせるものな どを有害微生物（有害菌）と呼んでいる。

これまでに分離，同定され働きが解明された微生物は 極めて多数にのぼる。そして，今までに得られた微生物 の情報は膨大であり，ごく最近では大腸菌，枯草菌や酵 母などいくつもの微生物の染色体DNAの全塩基配列が 決定されるなど，微生物に関する知識の集積は目覚まし いものがある。しかし，これら人類が認知しているもの は地上に存在する微生物のごく一部で, 多くのものは未 だに知られていないという。今後の研究によって地上の 微生物の全貌が解明され，そして人類に有用な働きをす る新しい微生物が次々と見つかることが期待される。

微生物は人類が誕生するはるか以前から長い時間をか けて多様に進化し，地上のあらゆるところで繁殖してい た。Table 1 には微生物が生息する極限的環境の一部を 示したが, 微生物は多様でどこにでも存在し様々な働き
をしている。そしてごく小さい生き物であるが，微生物 総体を地球規模で観察するとそのパワ一は想像を超える

ほど大きい。

一例をあげると，大気中の酸素が現在の濃度になり， ヒトをはじめとする高等生物が呼吸できるようになった のは微生物の作用のおかげである2。今から20億年以上 前の地球大気には酸素がほとんどなかった。進化の比較 的初期の過程で，酸素を放出する微生物（光合成細菌） が出現し膨大な時間にわたる作用によって，大気中の酸 素濃度が現在のレベルになった（Fig. 1参照)。そのお かげで，酸素呼吸をすることによって効率良くエネルギ 一を得る生物が現われ，ヒトの誕生へとつながった。も ちろん現在では地上の緑色植物による酸素の放出も膨大 であるが，海洋や湖沼などにいる無数の目に見えない微 生物による酸素の放出は, 依然として地球規模で重要な ものである。

その他に，窒素や炭素などの元素の循環についても， また地球環境の維持にとっても，微生物が総体として果 たしている役割はきわめて大きい。

\section{(2) 微生物, 細菌の持つパワーとは?}

それでは，目に見えない小さな微生物がどうしてその ような強力なパワーを発揮できるのであろうか？

その原因の第 1 は, 多くの微生物が細胞分裂によって 増殖するため， ネズミ算式に急速に増えることができる からである。

そのことを実感するために，大腸菌 1 個が最大速度で 分裂する場合をシュミレートしてみよう。条件が良けれ ば大腸菌は約 20 分に 1 回ずつ細胞分裂できるが, 細胞 の大きさを $\left(1 \times 1 \times 2 \mu \mathrm{m}^{3}: 1 \mu \mathrm{m}\right.$ は千分の $\left.1 \mathrm{~mm}\right)$ と 仮定すると，その重さは約 $2 \times 10^{-12} \mathrm{~g}$ となる（Table 2 )。最初は 1 個であるが, 1 時間後には細胞の総数は 8 個， 2 時間後には 64 個， 3 時間後には 512 個になる。 この調子で細胞分裂を繰り返すと，12時間後には $6.9 \times$ $10^{10}$ 個，約 $0.14 \mathrm{~g}$ となり細胞の塊が肉眼でも見えるよう

Table 1. Extreme conditions under which microbes can grow

\begin{tabular}{lll}
\hline Conditions & Range & Example of location \\
\hline Temperature & $-18{ }^{\circ} \mathrm{C} \sim 95^{\circ} \mathrm{C}$ & north and south poles; hot spring \\
Pressure & $\sim 1,400$ atom. & deep sea, etc. \\
Dryness & almost always dry & desert, etc. \\
Osmotic pressure & nearly saturation & Dead Sea, salty lake ; syrup \\
& nearly zero & fresh-water lake, etc. \\
$\mathrm{pH}$ & below $2 \sim 13$ & acidic spring ; alkaline lake \\
\hline
\end{tabular}


Table 2. Calculated total cell number and weight of bacterial cell which divides in every $20 \mathrm{~min}$.

\begin{tabular}{ccc}
\hline Hours & Total cell number & Total weight \\
\hline 0 & 1 & $2.0 \times 10^{-12} \mathrm{~g}$ \\
1 & 8 & \\
2 & 64 & $1.3 \times 10^{-10 \mathrm{~g}}$ \\
3 & 512 & \\
4 & $4.0 \times 10^{3}$ & $8.0 \times 10^{-9} \mathrm{~g}$ \\
6 & $2.6 \times 10^{5}$ & \\
12 & $6.9 \times 10^{10}$ & $0.14 \mathrm{~g}$ \\
18 & $1.8 \times 10^{16}$ & $36 \mathrm{~kg}$ \\
$24(1$ day $)$ & $4.7 \times 10^{21}$ & $9.4 \times 10^{3}$ ton \\
36 & $3.2 \times 10^{32}$ & $6.4 \times 10^{14}$ ton \\
48 (2 days) & $2.2 \times 10^{43}$ & $4.4 \times 10^{25}$ ton \\
\hline
\end{tabular}

(The earth : about $6 \times 10^{21}$ ton)

になる。そして18時間後には $1.8 \times 10^{16}$ 個，約 $36 \mathrm{~kg}$ に， 24 時間後には $4.7 \times 10^{21}$ 個，約 9,400 tonにもなる。たっ た 2 日後にはなんと $2.2 \times 10^{43}$ 個，約 $4.4 \times 10^{25}$ tonとなり， 地球の重さ（約 $6 \times 10^{21}$ ton）の 1 万倍近くにもなって しまう凄まじさである。もちろん，これは計算上のこと で実際にはこのようなことは起こらない。

しかし，栄養や温度など生育条件がととのえば数十分 に 1 回程度の速度で分裂する細菌はたくさんいるので, 上記のように猛烈な速度で増殖することは，局所的には あり得ることである。感染菌の增殖によって急激に病気 が悪化したり，室温に放置した食品が一晚で腐ったりす るのは, 有害微生物がきわめて速く増殖した結果である。 また，一方で，例之ば乳酸菌や納豆菌，酵母，放線菌な どが順調に増殖することによって，おいしいヨーグルト やチーズ，納豆，ビール，ワインなどの食品や，アミノ 酸, 抗生物質など有用物質が効率良く作られるのも，微 生物のこの増殖力のおかげである。

微生物パワーの他の原因として, 長時間の進化によっ てきわめて多様な性質をもつものが存在していること, さらに，環境の変化に応じて比較的容易に遺伝子を変化 させたり, 他の微生物から遺伝子を得て新しい環境に適 応する性質を獲得できること，などもあげられる。

人類は微生物を認識する以前から, 伝統的に微生物を 活用してきた。食品について言えば，世界各地で作られ ている酒，漬物，その他多くの発䤃食品の製造は，人類 の誕生以前から存在していた微生物の中で，食品の製造 や保存に役立つものを上手に培養して得られたものであ る。すなわち, 発酵原料や容器に生息する有用微生物 （酵母，桷かび，乳酸菌，納豆菌など）を植之継ぎ，そ のパワーを利用して伝統的発酵食品が作られてきた。発
酵食品の中には，ビール，ワイン，日本酒，ヨーグルト， チ一ズ, 味噌・醬油, 食酢, 漬け物などのように大量に 工業生産されているものもある。

さらに, 微生物によるアミノ酸や核酸, 食品用の各種 酵素などの生産も重要である。また，食品以外にも抗生 物質をはじめ多くの医薬品や各種有用物質（乳酸，酶酸 などの有機酸，酵素など）の製造，廃棄物処理などの環 境净化，さらには我々人間の腸内に定住して健康維持に 働くなど, 微生物はきわめて多様で重要な働きをしてい る。

これら各種の食品や有用物質の生産, 腸内の生理に関 与する数多くの微生物の分離, 同定, 生理, 発酵方法な どの解明や有用微生物の育種は人類にとって重要であり, 古くから研究が行われてきた。目に見えない微生物では あるが，そのパワーをうまく活用すれば有用な働きをさ せることができる。そのため, バイオテクノロジーを活 用する研究が精力的に進められている。

(3) バイオテクノロジーとは?

バイオテクノロジーとはなにか？。実は，この問に答 えることはきわめて難しい。広義には生物を対照とする 各種技術の総称であるが，一般には生命現象を解明し， または生物機能を利用するのに有用な最近の技術（遺伝 子組換之技術，細胞融合技術，バイオリアクター技術， 動植物のクローン技術など）を指す。そしてそれらの技 術の中でも，特に「遺伝子組換え技術」を指す場合が多 いようである。

遺伝子組換え技術が特に注目される理由は，他の方法 ではできないことがこの技術で可能になり，応用性が広 く効果が大きいからである。例えば，七卜成長ホルモン を大腸菌などに大量に作らせ，医薬品として利用するこ 


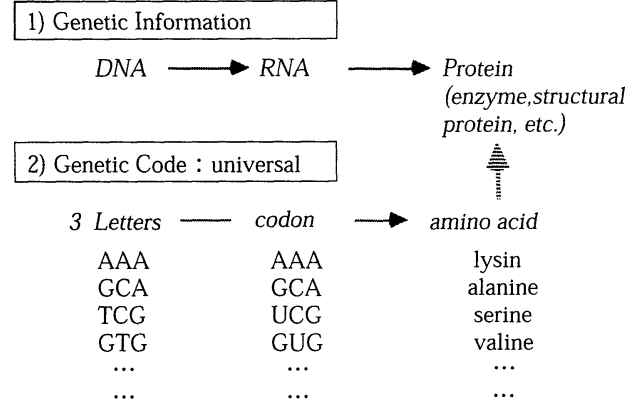

Fig. 2 Rules of genetic information

とは，従来の他の技術ではできなかったことである。

ではなぜこのようなことができるかといえば，地上の 生物が基本的に同一の遺伝原理に従っているからである。 すなわち，遺伝情報を核酸（主にDNA）に蓄えて子孫 に伝えその情報からRNAや蛋白質を作り出し様々な生 命現象を展開する，という基本原理は地球生物に共通で ある。しかも，遺伝情報が基本的に同じ暗号で書かれて いるので，ヒトか持つ遺伝情報が例えば大腸菌のような 下等生物にも同じ情報として働く（Fig. 2参照)。すな わち，DNAは 4 種類の塩基がつながってできているが， 塩基 3 個ずつの並びが 1 つの単位となって特定のアミノ 酸に対応する。そして，塩基配列に対応して順々にアミ ノ酸の並び方が指定されタンパク質が作られる。このや りかたが生物に共通なのである。

これは, 地球に誕生した最初の生命体が，ヒトをはじ 女現存するすべての生物の共通の祖先と考えられるから である。すなわち，地上の動物・植物・微生物は原初生 命体から同一の遺伝原理を受け継いでいるために，遺伝 情報の内容・流れが基本的に同じなのである。これが, ヒトの遺伝子を大腸菌で発現させることのできる生物学 的基礎である。

もちろん，七トのような高等動物と大腸菌のような下 等な微生物には細胞構造や遺伝様式などに違い(壁) が 存在するため, 自然界で両者の遺伝子が行き来して発現 することはない。遺伝子組換え技術によって，初めてこ のようなことが可能になったのである。

さて前置きが長くなったが, 細菌のバイオテクノロジ 一を理解するのに役立つポイントの解説に移ろう。遺伝 子を細菌に導入して，酵素などのタンパク質を作る場合 を例にして説明する。この場合，遺伝子は必ずしも細菌 由来である必要はない。しかし，七トなど高等生物の遺 伝子では，最終的にタンパク質となる遺伝情報が分断さ
れて存在する場合が多いので, こういう場合は, 予めメ ッセンジャーRNAから逆転写酵素を用いてcDNAを作 成して，細菌が読める形に遺伝情報を書き換えておく必 要がある。遺伝情報は全生物で基本的に同じなので，最 終的にできるタンパク質のアミノ酸配列は同じになり同 一のタンパク質ができる。

遺伝子を細菌に導入してその遺伝子から目的のタンパ ク質を作るためには，その細菌（宿主）で動く「プロモ 一ター」と呼ばれる塩基配列が必要である。プロモ一夕 一は，遺伝子情報をもとにしてメッセンジャーRNAが 作られる（転写という）反応を開始させるのに必要なも ので，発現しようとする遺伝子の上流に結合する。プロ モーターの配列はかなり共通しているが，種によって異 なるので宿主に適するものを選ぶ必要がある。プロモー ターは転写を調節するが，その種類によって，常に，ま たは，ある限定条件下（リン酸や糖などの存否，培養温 度など）でのみ転写を行わせることができる。さらにプ ロモーターによって, 転写量（最終的には遺伝子の発現 量，すなわち目的タンパク質の生産量）の制御を行うこ とができる。プロモーターの指令によってメッセンジャ 一RNAが作られるが，その終りを指令するのがターミ ネーターと呼ばれる塩基配列である（Fig. 3 )。

次に，遺伝子をどのように宿主細菌の細胞内に導入す るか, その方法について述べる。

まず，導入したい遺伝子を単離してべクターに結合す る。ベクターとは多くの場合プラスミドDNAで，目的

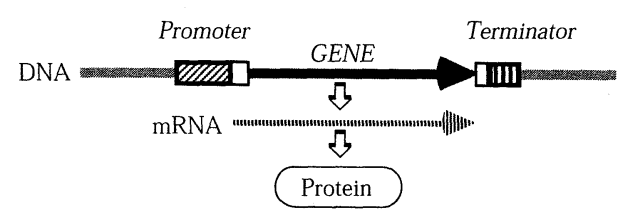

Fig. 3 A model of a bacterial gene structure and gene expression

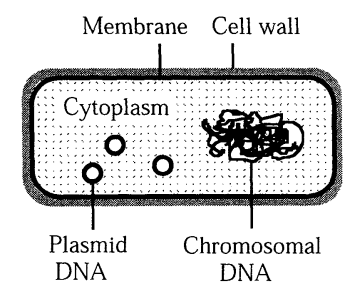

Fig. 4 A typical structure of a bacterial cell 
(A)

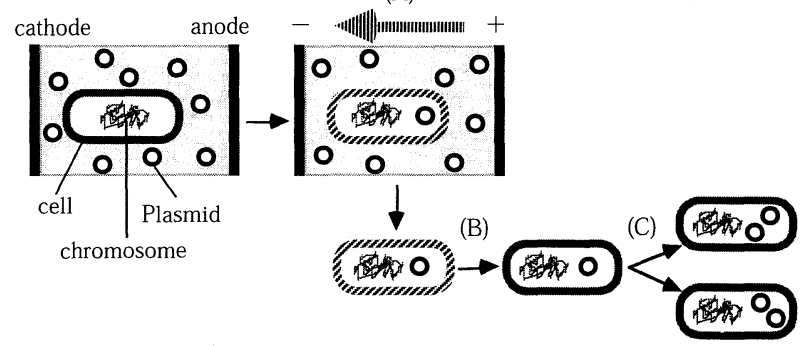

Fig. 5 Transformation by electroporation Host cells and plasmid DNA are suspended in a hypertonic buffer. (A) A high-voltage electric pulse is discharged and cell surface is damaged temporally. (B) Cell containing plasmid (transformant) is restored, and (C) cell division begins under a selective condition.

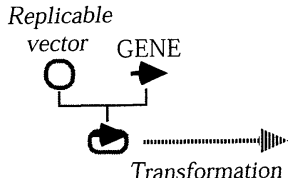

(A) Replication (multicopy, unstable)
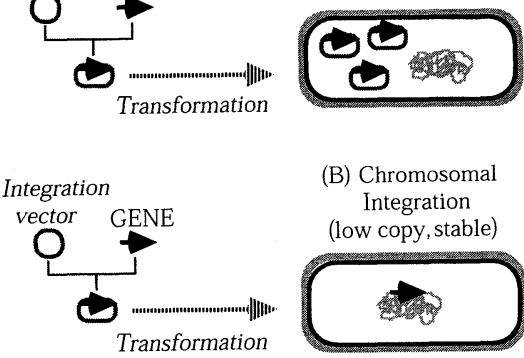

(B) Chromosomal Integration (low copy, stable)

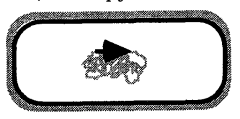

Fig. 6 Two ways of existence of the introduced gene in a bacterial cell

(A). Replication : the gene (black arrow) is multiplied owing to the replicable vector. (B). Chromosomal integration; the gene is integrated in the chromosome because the integration vector cannot replicate in the host. The integrated gene is duplicated according to the replication of the host chromosome.

の遺伝子を増幅し宿主に導入するための「運搬手段」で ある。プラスミドに目的遺伝子を結合して細胞内に導入 (形質転換) するが，一般にプラスミドが細胞内にうま く入る確率はあまり高くない。そのため, 細胞内でプラ スミドが導入されて複製するもの（形質転換体という） を選ぶことが必要で, ベクターには抗生物質耐性遺伝子 などの選択マーカーを付与しておく。

細菌の場合, 細胞質膜の外側に多糖などからなる細胞 壁という構造も持っているので（Fig. 4)，外から DNAを入れることはそれほど容易ではない。細菌の種 によって適用できるいくつかの方法があるが，効率よく 多くの細菌に使える方法は, エレクトロポレーション法
(電気穿孔法）と呼ばれるものである（Fig. 5 )。プラ スミドDNAと宿主細胞を高張液に懸濁し, 瞬間的に高 電圧電気パルスを印可して, 細胞表層構造を部分的に破 壊し（孔をあけ）プラスミドを導入する方法である。こ の処理により宿主細胞はダメージを受けるが，注意深く 培養すると, プラスミドが導入された細胞を増やすこと ができる。このような方法で, 選択条件（抗生物質添加 など）で生育する「形質転換体」を得ることができる。

さて, 導入する遺伝子を宿主細胞中でどのように存在 させるか大別して2つのやり方がある。1つは, 導入し たプラスミドを宿主細胞内で複製させる方法で, 他は宿 主染色体に組込む方法である（Fig. 6)。どちらの方法 を取るかは目的による。

前者は，宿主の細胞内で複製できるべクターを用い， 導入した遺伝子から作られるタンパク質やペプチドを生 産することを目的とする場合などに用いられる。ベクタ 一や培養条件にもよるが，目的の遺伝子を細胞当り数個 から百個くらいに増幅できるのでタンパク質などの大量 生産が期待できる。しかしこの方法の欠点は, 導入した プラスミドの構造か湾化したり, 非選択条件下で失われ るために不安定なことが多いということである。

一方，染色体組込みは，宿主で複製できないべクター に目的の遺伝子を扱入して「組込みプラスミド」を構築 し，組換え反応によって宿主染色体に組込ませる方法で ある。多くの場合, 染色体と相同な塩基配列をべクター に付けて，宿主の組換え能を利用して（相同組換え）組 込み頻度を高める。この方法による遺伝子導入効率は, 複製できるべクターの場合に比べると極めて低いが，そ の利点は, 導入した遺伝子が細胞分裂に伴う染色体の複 製と同調して複製されるため, 安定に保持されることで 
ある。ただし多くの場合, 染色体に組み込まれるプラス ミドは 1 ないし数コピ一程度であるため, 遺伝子の数を 多くすることは難しい。

今までの微生物育種・改良は，自然界からの選抜，突 然変異, または接合, プロトプラスト融合などで行って きたため，目的とする性質をもつ改良株の作成はいわば 運まかせで，きわめて困難な作業であった。しかし，遺 伝子さえ取得できれば上記のような方法で, 目的の遺伝 子を導入したり, 染色体の遺伝子を付加・交換・欠失し たりできる。すなわち，バイオテクノロジーによって， 産業的に有用な微生物を合理的かつ効率良く改良するこ とが可能である。しかも遺伝的な改良を，宿主微生物の 他の遺伝情報を変えることなく実行できるので，産業的 に有用な性質を残したまま育種ができる点が従来の技術 より優れている。したがって, 今後この手法が広く応用 されることは確実であると考えられる。

以上が，細菌のバイオテクノロジー（遺伝子組換え技 術）の理解に役立つと思われる簡単な解説である。これ らを参考にして，以下を読んで頂きたい。

\section{2 乳酸菌と人間のかかわり}

\section{（1）乳酸菌とはなにか}

乳酸菌は，食品製造をはじめ最も身近で有用な働きを する細菌で, 今後も広い分野での応用が期待されてい る3)。

御承知のように，「乳酸菌」とは特定の菌種を指す科 学用語ではなく，ある共通な性質を持つ一群のグラム陽 性細菌の総称である。乳酸菌に共通な性質として, 糖を 代謝し多量の乳酸を生成する, 娧気条件や弱酸性でもよ く生育する，アミノ酸やビタミンなど多くの栄養素を生 育に要求する, 運動性がなく胞子形成をしない, 病原性 がないなどであるが, なんと言っても, 我々の食生活と のつながりが強いことが特徴であろう。分類学の進展に より, 現在では乳酸菌は, Lactobacillus, Lactococcus, Streptococcus, Enterococcus, Pediococcus, Tetragenococcus, Leuconostoc, Weissella, Oenococcus, Carnobacterium, Vagococcus, Atopobium，などの属に分類される ${ }^{4)} 。$

乳酸菌は，世界中の数多くの発酵食品の製造に関わつ ている ${ }^{5)}$ (Table 3)。乳を原料としてチーズ・ヨーグル トなど, 畜肉・魚肉からは, 発酵ソーセージ, アンチョ ビ，ふなずしなど，さらに植物を原料として，各種の漬 物，味噌・醬油，日本酒・ワイン，サワーブレッドなど が作られる。これらの原料には多くの栄養素が含まれて おり，栄養要求性を示す乳酸菌が増殖するのに適してい るため昔から住みついてきたと思われる。乳酸菌が関
Table 3. Foods fermented by lactic acid bacteria

\begin{tabular}{ll}
\hline \multicolumn{1}{c}{ Original food } & \multicolumn{1}{c}{ Fermented food (feed) } \\
\hline MILK & $\begin{array}{l}\text { Cheese, Yogurt, Kefir, Fermented } \\
\text { butter }\end{array}$ \\
MEAT, FISH & $\begin{array}{l}\text { Fermented sausage, Anchovy, Funa } \\
\text {-zushi }\end{array}$ \\
VEGETABLE & $\begin{array}{l}\text { Sauerkraut, Kimuchi, Takuwan, } \\
\text { (Silage) } \\
\text { CEREALS }\end{array}$ \\
& $\begin{array}{l}\text { Wine, Sake, Miso, Soy sauce, Sour } \\
\text { bread }\end{array}$ \\
\hline
\end{tabular}

わる発酵食品の数はきわめて多いが，逆に，日本酒の火 落ちや生ビールの混濁など，乳酸菌が食品污染の原因と なることもある。

そのほかにも, 乳酸菌は家畜の保存飼料であるサイレ 一ジの生産や, 乳酸・デキストラン・ナイシンなどの有 用物質製造にも使われる。また，一部の乳酸菌はヒトの 腸内有用菌として働いているが，その作用を活かして整 腸剂や乳酸菌製剂が作られている。

\section{(2) 乳酸菌の利用と研究の歷史}

以上のように乳酸菌は有用であり産業的にも重要な菌 である。乳酸菌が発見されたのは今から百年ほど前であ るが，人類ははるか以前から乳酸菌を利用してきた。

ヒトが生まれ出たのは，微生物が進化し様々な環境で 棲息し多様な作用を及ぼしている，いわば，地球が無数 の微生物に満ちている中であった。したがって，ヒトが 誕生した時には乳酸菌はすでに現在と同様な働きをして いたと思われる。乳酸菌によって好ましく変化した食品 （おいしく，保存性の増した発酵食品）を，人類は偶然 発見し，自然の恩恵として享受した。

その後，これら乳酸菌による発酵食品を自らの手で作 るべく人類は様々な工夫をしてきた。ヨーグルトのよう に発酵食品の一部を乳酸菌の「種（たね）」として使っ たり，ワインなどのようにもともと原料に付着していた 乳酸菌を知らずに利用し，数多くの経験から失敗の少な い製造法を確立していった。この過程は，いわば有用菌 を同一条件で培養して望ましい菌株を選択する操作でも あった。乳酸菌の中にはこのような過程によって影響を 受け変化したものがある（例えば，チーズ製造に用いら れる乳酸菌のうちクレモリス菌は，自然界から分離され ずほとんどチーズなど発酵乳製品にのみ存在する。いわ ば発酵乳を自らの棲息場所にしたかのようである)。

人類の移動に伴って乳酸菌はいろいろな所に伝播され， 世界中で乳酸菌を用いた多様な発酵食品が作られるよう 
になった。そして19世紀半ばになって，チーズなどの 発酵孚製品が工業規模で作られるようになり，より良い 製品を安定して大量に作るため乳酸菌の研究が本格的に 進められた。

乳酸菌を発見したのは，かの有名なフランスのルイ・ パスツールであり1857年のことである。その後, 発酵 乳製品をはじめ多くの発酵食品から乳酸菌が分離され分 類が試みられ，近代的な研究が開始された ${ }^{6) 。 ~}$

初期の研究の中で特筆すべきものは, 主として欧米の 研究者によるチーズ製造用乳酸菌 (Lactococcus属) の 研究である。チーズは, 腐敗しやすい牛乳を原料として, 乳酸菌の作用などで作られる栄養豊かな保存食である。 チーズ製造は酪農国でもある欧米にとって経済的にきわ めて重要であり，多くの研究が行われてきた。そして， チーズ乳酸菌の乳糖取込みと代謝，ならびに牛乳中の夕 ンパク質分解，ペプチドの取込みとアミノ酸への分解な どが詳細に研究された。また，チ一ズ製造は開放系で行 われるため，ファージ（乳酸菌に感染するウィルス）の 被害が甚大でその研究も盛んに行われた。さらに，千一 ズ製造に関わるいくつかの重要な性質（カゼインなどを 分解する蛋白質分解活性，乳糖の資化性，ファージに対 する耐性，制限修飾活性，クエン酸資化性など）が, Lactococcus属ではプラスミド上の遺伝子にコードされ ていることが判明しプラスミドの研究が行われた7)。ま た,これらのプラスミドが，時として乳酸菌から失われ チーズ製造停滞の原因となることも判明した。そして， プラスミドの接合伝達 $\left.{ }^{8}\right)$, 乳酸菌ファージによる形質導

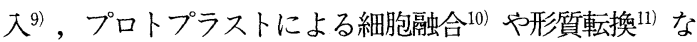
どの方法による育種が試みられた。

これら産業的応用を目指して行われた一連の研究は， 今日の乳酸菌バイオテクノロジーの発展に直接つながる 重要な研究成果となっている。

\section{3 乳酸菌のバイオテクノロジー}

乳酸菌のバイオテクノロジーは1980年代の研究によ ってその基礎が確立し，ここ十年ほどの間に次々と技術 が開発されて，応用研究がさかんになった。食品製造は もちろん「健康」との関連て乳酸菌が持つ可能性が広く 注目されていることを背景として，世界の多くの研究者 がこの分野に加わり，急速に研究が進展している ${ }^{12)} 。$

\section{（1）各種基礎技術の確立}

技術的進展としてまず, エレクトロポレーション法 (前述のFig. 5 参照) による形質転換の成功が挙げら れる。1987年に細菌では初めてインタクト細胞を用い た形質転換がチーズ製造乳酸菌Lactococcus lactis（Lc. lactis）で報告された ${ }^{13)}$ 。それまで乳酸菌では一部の例 外を除いて形質転換が困難であったが，本方法によって 乳酸菌のほとんどの属で形質転換が可能となった。制限 修飾系を欠損した宿主を用いて $1 \mu \mathrm{gDNA} て ゙ 10^{7}$ 個もの 形質転換体が得られる場合もある14)。

また，乳酸菌プラスミドをもとにして，乳酸菌用の広 宿主域べクタ一が構築され，様々な発現べク夕一，分泌 ベクターなども作られた。したがって，今のところ $L c$. lactisをはじめとする一部の菌株では，異種遺伝子の導 入やその発現がかなり自由に出来るようになった。

さらに，乳酸菌染色体への遺伝子導入法の確立も重要 である。遺伝子操作した乳酸菌を食品などへ応用する場 合, 「安全性」が何よりも求められる。したがって, 目 的の遺伝子のみを染色体に組込んで, ベクタ一など不要 な配列が残らないようにする事が必要である。この基準 を満たすものとして，2回の「相同組換え」を経て目的 遺伝子を染色体に組込む方法 ${ }^{15)}$ が用いられている。また， 高温感受性の複製を示すべクター16) を用いて，低温で形 質転換体を 1 個以上得たのち，高温の選択条件で培養し てプラスミドを染色体に組込む方法も用いられている。 これは，形質転換効率が低いため染色体へ直接遺伝子を 組込むことが困難な「産業株」などへの応用に適する。

\section{（2）乳酸菌染色体の解明}

各種の乳酸菌遺伝子がクローニングされ，多くの情報 が集積している。特に, 乳糖資化に関する遺伝子, カゼ インなどを分解するプロテア一ゼ遺伝子や各種のぺプチ ダ一ゼ遺伝子, 乳酸脱水素酵素遺伝子, ファージ耐性遺 伝子，バクテリオシン関連遺伝子，など産業的利用と関 連が深い多くの遺伝子が解明されている。

またここ数年の間に，いくつかの乳酸菌の染色体制限 酵素地図が作成され，乳酸菌染色体が環状で約 $1.8 \sim 2.6$ $\mathrm{Mb}$ のきさであることが判明した ${ }^{17)}$ 。制限酵素地困上 に，すでに解明された遺伝子や細菌で広く保存されてい る遺伝子がマップされて, 乳酸菌で初めて染色体地罒が 作成された。接合や形質導入などの手法が使えないため 作成できなかった乳酸菌の染色体地図が作られた意義は 大きい。

最近, 大腸菌, 枯草菌や酵母をはじめ各種の微生物で 染色体の全塩基配列が決定されたが，乳酸菌でもゲノム 解析計画が進行中である（Table 4$)$ 。早ければ今年中 にも，乳酸菌で初めて染色体全塩基配列が決定されると 思われる。ただし，多くの計画は食品企業などがからん でいるため，塩基配列情報が自由に利用できるかどうか はわからない。いずれにせよ，染色体の全塩基配列情報 が得られるようになれば，乳酸菌バイオテクノロジーの 
Table 4. Genome Project of Lactic Acid Bacteria

\begin{tabular}{ll}
\hline Stage & Species or strain (Nation ; Organization) \\
\hline In Progress & Lactococcus lactis subsp. lactis IL1403 \\
& (France ; INRA \& dairy company ?) \\
& Lactobacillus acidophilus \\
& (U. S. A. ; North Carolina State Univ. \& companies?) \\
& Lactobacillus johnsonii \\
& (Switzerland ; Nestle S. A.) \\
& Lactococcus lactis subsp. cremoris MG1363 \\
Planned & (EU, The Netherlnads ; Univ. of Groningen) \\
& Streptococcus thermophilus ( ? ) \\
Uncertain & Lactobacillus acidophilus ( ? ) \\
& (Europe; food companies? ) \\
\hline
\end{tabular}

基礎および応用研究は確実に新たな段階に突入し，より 一層の進展が期待できる。

\section{(3) バイオテクノロジーの研究例}

乳酸菌バイオテクノロジ一の応用研究は世界中で精力 的に行なわれている。そのうちのほんの少数であるが, いくつかの例を紹介する。

(1) 乳中では遊離アミノ酸の量が少ないので, 乳で生 育する乳酸菌はカゼインなどの蛋白質を分解してアミ， 酸を補給しなければならない。チーズ製造乳酸菌 $L c$. lactisではこの反応系が詳細に調べられた。

細胞表層に結合する蛋白質分解醏素の遺伝子がプラス ミドにコードされていることが判明した18) が，本遺伝子 を染色体に組込んで安定化し，同時に遺伝子増幅によっ て蛋白分解活性を増強した研究がある ${ }^{19)}$ 。また, ペプチ ドを細胞内に取込む系や, 細胞内に存在する各種のペプ チダーゼとそれらの遺伝子も解明され，遺伝子破壊によ って各々の役割までが検討されている20)。

これらの研究の応用として，例えば苦味ぺプチドを作 らない菌株を育種するなど，チーズの香味改良に役立て る研究が進んでいる。そのほか, 発酵停滞の原因となる ファージに対する耐性を付与する研究など21)，チーズ乳 酸菌の改良を目指寸研究は欧米で広く行われ，実用まで あと一歩の所に来ている。

(2) 一部の乳酸菌は, 近縁菌に対して抗菌作用を示す ペプチド (バクテリオシン222) を産生する。その中でも ナイシンは，欧米を含む多くの国で污染菌を抑えるため の防腐剂として使われている。その生産及び免疫に関す る遺伝子がクローニングされ，蛋白質工学を用いて改変 して活性を高めたり抗菌スペクトルを拡げるなどの試み が行なわれている。
また，ナイシン自身が，十イシンの産生をポジティブ に制御することが判明した ${ }^{23)}$ 。すなわち，細胞外に分泌 されたナイシン分子が細胞表層にあるレセプターに結合 し，その情報が細胞内に伝達されて，十イシンのプロモ 一ターが活性化される。この現象を応用して, 蛋白質の 大量発現を目指す研究が活発に行われている。すなわち, 目的の蛋白質遺伝子にナイシンプロモーターをつけ，こ のプラスミドで形質転換した株を, 生育が阻害されない ごく低濃度の十イシンを加えて培養すると, プロモータ 一が活性化されて蛋白質が大量に作られる24) 例が示され 広い応用が期待されている ${ }^{25)}$ 。

(3) 遺伝子操作で改良した乳酸菌を食品に応用する場 合,「安全性」が必須要件である。実験的に選択マーカ 一として用いられている抗生物質耐性遺伝子ではなく, 食品に応用できる「安全な選択マ一カー」が求吼る。 乳酸菌由来のバクテリオシン耐性遺伝子, 糖代謝遺伝子, 核酸合成酵素遺伝子など，種々の検討が行なわれている。

また, 前述の様に, 2 回の相同組換えで目的の遺伝子 のみを染色体に導入して安全性を確保する試みも種及行 なわれている。筆者らのグループは，ヨーグルト生産菌 であるブルガリア菌染色体の乳酸脱水素酵素 (LDH) 遺伝子を，同じヨーグルト生産菌であるサーモフィルス 菌のLDH遺伝子と交換してL-乳酸を生成する株（遺伝 子交換株）を作成した ${ }^{26)}$ 。元の株と比べると，LDH遺 伝子のみが異なっていることが確かめられたため，この ような育種法は安全性確保に適しているといえる。

(4)さらに，新しい応用として注目すべきものは，乳酸 菌を抗原運搬体とする「経口ワクチン」の開発であり, 乳酸菌が多量に経口摄取しても安全である点を活かそう としている27)。各種の方法か検討されており, 目的の抗 


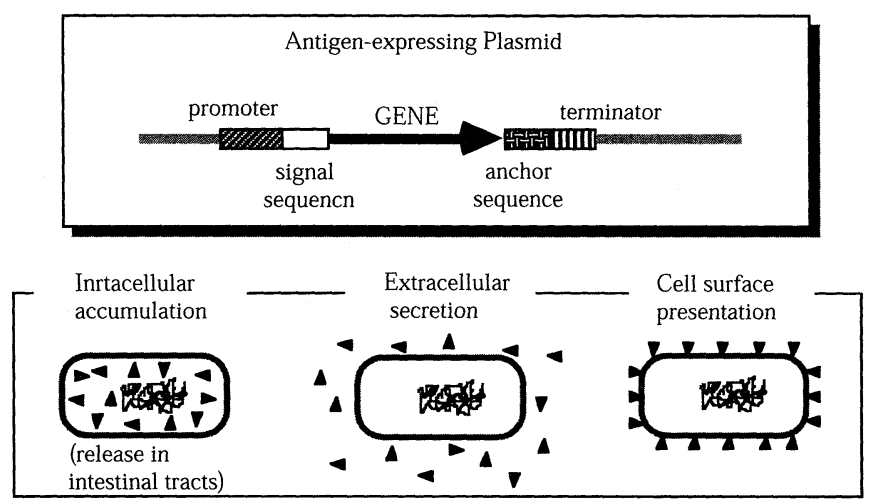

Fig. 7 Antigen-expressing plasmid (upper) and three tactics (below) for production of the antigen molecules (closed triangles)

原を細胞内で作らせ腸内で乳酸菌が溶菌する時に放出す る，菌体外に分泌生産し直接経口的に摄取する，あるい は膜アンカーシグナルを利用して乳酸菌細胞表層に抗原 分子を提示する，などである（Fig. 7 )。

主に欧州の研究機関で研究が進められているが，多く の抗原蛋白質・ペプチドの発現が試みられ，動物実験で 効果が確かめられたものもあり今後の展開が期待される。

(5) 食品以外のほかの例として, 家畜の保存飼料であ るサイレージ生産を効率良く進めるために，乳酸菌に植 物多糖を分解する酵素の遺伝子を導入した研究などがあ る $^{28)}$ 。

また，乳酸を原料とする生分解性の「ポリ孚酸樹脂」 の生産も注目される。これには乳酸生成効率の良い菌株 が使われているが，遺伝子操作によってさらに生産効率 が上がればコストが低下して生分解性樹脂の消費か増大 し，地球環境の保全に寄与することも考えられる。

\section{おわりに}

以上，数例で不十分ではあるが，乳酸菌のバイオテク ノロジーが近年急速に進展している姿を紹介したつもり である。今まで困難だった産業株の育種はもはや単なる 夢ではなく，合理的な設計さえできれば実現可能な課題 となっている。

遺伝子操作を応用して，既存食品については失敗のな い効率的な生産, 香味など品質の改良を進めることが充 分期待できる。さらに将来の応用として, 乳酸菌の持つ 顕在的及び潜在的な可能性を最大限に引き出し, 健康関 連分野で活用することが有望である。乳酸菌に「健康生 理効果」のある蛋白質やへプチドを作らせ，健康の維 持・増進効果をもつ食品を作り出すことも可能であろう。
今のところは実用例はないが，おいしく体に良い乳酸 菌発酵食品や，乳酸菌を利用した新しい医薬品が作られ， 人類に多くの貢献をすると期待される。もち万ん遺伝子 操作した乳酸菌株を応用するには，なんといっても安全 性の確保が大前提であり, 開発にあたっては慎重な科学 的検討が必須である29)。今までの研究によって，食品製 造に用いてきた乳酸菌の遺伝子のみを使い, 安全な方法 で乳酸菌を改良する技術は確立しつつある。乳酸菌には 多くの可能性と未来がある，と筆者は信じている。乳酸 菌についてもっと詳しく知りたい方は，書籍「乳酸菌の 科学と技術」(学会出版センタ一) を参照することをお 勧めしたい。

なお，前半の解説が長くなったが少しでも参考になる と感じていただければ幸いである。

\section{文 献}

1) 柳田友道: 微生物科学第 1 巻（学会出版センター, 東京), p.30 (1980)

2 ) 中村桂子ら監訳：細胞の分子生物学第 3 版（ニュー トンプレス，東京), p.16（1995）

3）森知敏樹：ミルクサイエンス，46，1 (1997)

4 ) 鈴木健一朗: 乳酸菌の科学と技術（学会出版セン夕 一, 東京, 乳酸菌研究集談会編), p.37 (1996)

5 ）橋場炎ら：乳酸菌の科学と技術（前出）, p.229 (1996)

6) SANDINE W. E. : FEMS Microbiol. Rev., 46, 205 (1987)

7) MCKAy, L. L. : Antonie van Leeuwenhoeck, 49, 259 (1983)

8) GASSON, M. J. and DAvies F. L. : J. Bacteriol., 
143, 1260 (1980)

9) Allen, L. K. et al. : J. Dairy Res., 30, 351 (1962)

10) GASSON, M. J. : FEMS Microbiol. Lett., 9, 99 (1980)

11) Kondo, J. K. and MCKAY L. L. : Appl. Environ. Microbiol., 43, 1213 (1984)

12）佐々木隆：バイオサイエンスとインダストリー,

53，950 (1995)

13) HARLANDER, S. K. : "Streptococcal Genetics" (ASM, Washington D. C.), p.229 (1987)

14) Holo, H. and NES I. F. : Appl. Environ. Microbiol., 55, 3119 (1989)

15）佐々木泰子：バイオサイエンスとインダストリー, 52, 106 (1994)

16) BisWAS, I. et al. : J. Bacteriol., 175, 3628 (1993)

17) LE BourgeOIS, P. et al. : FEMS Microbiol. Rev., 12, 109 (1993)

18). KoK, J. : FEMS Microbiol. Rev., 87, 15 (1990)

19) Leenhouts, K. J., et al. : Appl. Environ.
Microbiol., 57, 2568 (1991)

20) KUNJI, E.R.S., et al. : Antonie van Leeuwenhoeck, 70, 187 (1996)

21) HiLl, C. : FEMS Microbiol. Rev., 12, 87 (1993)

22) NES, I. F., et al. : Antonie van Leeuwenhoeck, 70, 113 (1996)

23) Pascalle, G. G. A, et al. : J. Bacteriol., 178, 3434 (1996)

24) KuIPERS,O. P., et al. : Trends Biotechnol, 15, 135 (1997)

25) Eichenbaum, Z., et al. : Appl. Environ. Microbiol., 64, 2763 (1998)

26）佐々木隆・佐々木泰子・伊藤喜之：ミルクサイエ ンス, 47，77 (1998)

27) Wells, J. M., et al. : Antonie van Leeuwenhoeck, 70, 317 (1996)

28) Fitzsimons, A., et al. : Appl. Environ. Microbiol., 60, 3529 (1994)

29) Verrips, C. T. and D. VAN DEN BERG J. C. : Antonie van Leeuwenhoeck, 70, 299 (1996) 